\title{
Mammographer personality traits - elements of the optimal mammogram experience
}

\author{
Authors: \\ Amanda Louw ${ }^{1}$ \\ Heather Lawrence ${ }^{1}$ \\ Jenny Motto ${ }^{1}$ \\ Affiliations: \\ ${ }^{1}$ Faculty of Health Sciences, \\ University of Johannesburg, \\ South Africa \\ Correspondence to: \\ Amanda Louw \\ Email: \\ amandal@uj.ac.za \\ Postal address: \\ 58A Toby Avenue, \\ Johannesburg 2092 \\ South Africa \\ Dates: \\ Received: 05 Dec. 2013 \\ Accepted: 13 Aug. 2014 \\ Published: 07 Nov. 2014 \\ How to cite this article: \\ Louw, A., Lawrence, \\ H. \& Motto, J., 2014, \\ 'Mammographer personality \\ traits - elements of the \\ optimal mammogram \\ experience', Health SA \\ Gesondheid 19(1), Art. \\ \#803, 7 pages. http://dx.doi. \\ org/10.4102/hsag.v19i1.803

\section{Copyright:} \\ (C) 2014. The Authors. \\ Licensee: AOSIS \\ OpenJournals. This work \\ is licensed under the \\ Creative Commons \\ Attribution License.
}

Read online:
Background: Mammography is not supported optimally by patients as a screening and diagnostic tool for breast cancer, often as result of negative perceptions amongst patients which originate from a range of factors.

Objectives: The objective of the wider study was to probe some of the factors impacting on patient perceptions. This article reports findings regarding patients' preferences and perceptions concerning mammographer personality traits.

Method: Descriptive, exploratory research employed a non-probability, convenience sampling method to collect data by means of a questionnaire from 274 mammogram patients in four clinical training centres in Gauteng. Respondents had to rate 24 personality traits in mammographers in terms of importance. Validity, credibility, reliability and ethical considerations were addressed.

Results: A questionnaire return rate of $91 \%$ was achieved. Descriptive statistics and factor analysis facilitated interpretation of the data and four factors emerged from the personality trait scale.

Conclusion: Patients seem to rate mammographers in terms of the trust they instil, the care that they emanate, how safe they make patients feel and how well they communicate. As mammographer-patient interaction plays an integral role in the way patients perceive mammogram experiences, these factors are conceptualised as also being fundamental elements of an optimal mammogram experience.

Agtergrond: Mammografie word nie optimaal deur pasiënte as diagnostiese en siftingsmetode vir borskanker ondersteun nie, deels as gevolg van pasiënte se negatiewe perspepsies daarvan, wat aan 'n veskeidenheid faktore toegeskryf kan word.

Doelstellings: Die doel van hierdie studie was om van die faktore wat pasiënte se persepsies beïnvloed, te ondersoek. Pasiënte se persepsies en voorkeure ten opsigte van mammograwe se persoonlikheidseienskappe word in hierdie artikel bespreek.

Metode: In dié beskrywende, verkennende studie is 'n nie-waarskynlikheidgerieflikheidsteekproef-metode gebruik om data van 274 mammogram-pasiënte in vier kliniese opleidingsentrums in Gauteng met behulp van ' $n$ vraelys in te win. Die respondente moes die belangrikheid van 24 persoonlikheidseienskappe van mammograwe beoordeel. Geldigheid, betroubaarheid, geloofwaardigheid en etiese oorwegings is in ag geneem.

Resultate: Van al die vraelyste is $91 \%$ ingehandig. Die data is met behulp van beskrywende statistiek en faktoranalise geïnterpreteer, en vier faktore is uit die persoonlikheidskaal geïdentifiseer.

Gevolgtrekking: Dit blyk dat pasiënte mammograwe beoordeel volgens die vertroue wat hulle inboesem, die sorg wat hulle verleen, hoe veilig hulle pasiënte laat voel, asook hoe goed hulle kommunikeer. Aangesien die mammograaf-pasiënt-verhouding pasiënte se indrukke van mammogramme sterk beïnvloed, kan hierdie vier faktore as fundamentele elemente van 'n optimale mammogram-ondersoek beskou word.

\section{Introduction}

Patients' perceptions of the different aspects of a mammogram examination determine largely the manner in which they evaluate the overall mammogram experience. Negative experiences may result in reluctance to report for follow up mammograms and therefore, in the interest of good mammogram attendance rates, steps should be taken to improve patient perceptions (Davey 2007:229; Doyle \& Stanton 2002:159; Legg 2000:437). One of the major factors impacting 
on patients' perceptions is the mammographer who performs the examination (Doyle \& Stanton 2002:160; Legg 2000:438).

This article, based on results of a study of the preferences and perceptions of female patients undergoing mammography in Gauteng, South Africa, focuses on the preferences of female patients concerning mammographer personality traits and their effect on the way patients perceive mammogram examinations. It is argued that a better understanding of the factors influencing patient perceptions is essential for improving on existing perceptions and experiences in order to encourage higher mammogram attendance rates. In this article, literature related to the role of the mammographer is introduced, the survey is explained, the results are discussed and a concept to be developed through future research is suggested in order to facilitate the optimal mammogram experience for South African women.

\section{Literature review}

About 6000 women in South Africa are diagnosed annually with breast cancer and an estimated 3000 die each year of the disease. It is the most prevalent form of cancer amongst white and Asian women and the second most common cancer in mixed-race and black women (Pinklink 2007). Benefits of early detection include a decrease in the mortality rate and less-invasive treatment (Barth et al. 2005:324; Ikeda 2004:x1). Although mammography is the most effective way of detecting early breast cancer, international statistics indicate suboptimal adherence to screening mammogram recommendations (Poulos \& Llewellyn 2005:18-25; Swan et al. 2003:1528).

International studies draw attention to the fact that mammographers influence the way in which patients perceive mammogram examinations and that perceptions, whether negative or positive, affect attendance rates (Davey 2007:229; Doyle \& Stanton 2002:160; Kamm 2000:261; Legg 2000:438). The mammographer's role is complex, necessitating a high standard of technical competency, good communication skills and the ability to limit patient anxiety and discomfort (Legg 2000:438; Long et al. 2010:581; Peart 1994:37). Certain personality traits seem to enhance their ability to handle this complex task, namely, respect, compassion and being an effective and informative communicator, which are essential elements of the mammographer's patient care regime (Kamm 2000:257). Being friendly, reassuring, courteous and helpful are central to ensuring a patient's satisfaction with breast-screening examinations, whilst the need for sensitivity, maturity and empathy, along with the willingness to listen to patients, are also highlighted (Doyle \& Stanton 2002:161; Poulos \& Llewellyn 2005:18-25).

No South African research pertaining to mammographers was found but, according to the National Patients' Rights Charter, all patients have the right to be treated by healthcare providers demonstrating courtesy, empathy, patience, tolerance and a positive disposition (HPCSA
2008). As radiographers, of which mammographers form a subcategory, fall under the classification of healthcare providers, it is thus accepted that these personality traits are also to be expected of those mammographers practising in South Africa (Etheredge 2011:12). A variety of desired personality traits in mammographers has thus been identified in both national and international literature.

\section{Purpose}

This comprehensive study aimed to establish the preferences and perceptions of female mammography patients with regard to student participation in the examination, as well as mammographer gender and personality traits. To preclude memory bias and to ensure an accurate portrayal of these concepts, participants received a questionnaire immediately after completion of their mammogram examination.

\section{Research method and design Design}

The study followed a descriptive, exploratory design and a non-probability, convenience sampling method was employed. In each of four clinical training centres affiliated to the Department of Radiography, University of Johannesburg, questionnaires were distributed to 75 mammogram patients (totalling 300). These centres were selected to represent specific geographical areas in order to ensure a sample ranging in probable patient income and ethnicity.

\section{Materials}

Research information letters were handed by the reception clerks to all female patients 20 years and older who reported for mammogram examinations and who could answer questionnaires in English without assistance. After completion of the standard patient information forms, the patient had time to read through the research information sheet which explained the aims of the study and invited the patient to participate.

\section{Data collection method/procedure}

Immediately after the mammogram procedure, the mammographer reminded the patient of the study and, if the patient indicated willingness to participate, she received a questionnaire to complete whilst the mammographer left the room to discuss the images with a radiologist. The patient thus had private time to complete the questionnaire. When designing the methodology, it was decided not to have research assistants and to have the patient alone whilst she was filling in the questionnaire so as to avoid bias resulting from a research assistant's possible preconceptions and/or the patient's desire to please either the assistant or mammographer. Staff were also requested not to discuss the study with the patients. These measurements were deemed necessary in order to increase the credibility of the data, specifically because the questionnaire tested the very personal emotions, opinions and preferences of patients. 


\section{Context of the study}

One of the questions required respondents to rate 24 listed personality traits in mammographers in order of importance on a four-point Likert scale. The list was compiled from personality traits which emerged as being desirable from studies in Australia, Ireland, the United Kingdom, two literature reviews, a Canadian textbook and the National Patient's Rights Charter (Davey 2007:232; Doyle \& Stanton 2002:164-165; HPCSA 2008; Kamm 2000:257; Legg 2000:438; Long et al. 2010:581; Poulos \& Llewellyn 2005:24). The selected personality traits thus represented a combination of traits which were identified as a result of interaction within various interest groups, both nationally and internationally, and it was decided to test these personality traits in an exclusively South African context.

\section{Results}

A return rate of $91 \%$ was achieved, with 274 of 300 questionnaires returned. Unfortunately, not all respondents answered all the questions. A reason for this might be that some did not understand all the questions and, as they were alone, no one could clarify their uncertainties. The non-response rate for individual questions ranged between $3 \%$ and $35 \%$, which indicates that some questions had a response rate of only $65 \%$ if compared to the overall response rate $(n=274)$ and $60 \%$ if compared to the sample size $(n=300)$. As this was still considered to be an acceptable response rate and representative of the target population, the partially-completed questionnaires were included in the statistical process in order to allow conclusions to be drawn from the highest possible number of responses for individual questions. The count for individual items on the personality trait section of the questionnaire indicated that $11 \%$ to $22 \%$ of the participants did not score certain items. In this article, valid percentages (the number of responses per variable, expressed in terms of the number of respondents who answered the specific question) will be reported.

Data were analysed using the Statistical Package for the Social Sciences v.15 software package (SPSS Inc., Chicago 2006). Descriptive and inferential statistics were used to interpret the variables and their correlations. Chi-squared tests, $t$-tests and analyses of variance (ANOVAs) were performed and correlations were considered to be of statistical significance if $p<0.05$. Factor analysis facilitated interpretation of the personality scale results.

\section{Demographics}

Only a few respondents fell into the youngest age group whilst most were in the 40 to 49 year age group. The respondents were mainly white women, which is in line with United States statistics, where white women have more mammograms than any other ethnic group (Farmer et al. 2007:117; Kamm 2000:249). The majority were married or cohabiting, being in contrast with literature which reports that marital status impacts negatively on mammogram attendance (Kamm 2000:252). In addition, most respondents only had school-level education, which is in contradiction with international studies which report that more highlyeducated women are most likely to have mammograms (Fowler 2006:248; Kamm 2000:248). Table 1 presents the demographics of the respondents.

\section{Personality traits}

The personality traits that were identified as being most important, with a score higher than $50 \%$, were observant (59\%, $n=135)$, informative $(57.8 \%, n=137)$, honest $(57.2 \%$, $n=139)$, dedicated $(55.7 \%, n=128)$, gentle $(54.3 \%, n=133)$, friendly $(51.3 \%, n=123)$, patient $(51.1 \%, n=118)$ and positive attitude $(50.9 \%, n=118)$. Personality traits that were identified as unimportant, with a score higher than $8 \%$, were quiet $(30.7 \%, n=66)$, inquisitive $(27.1 \%, n=58)$, talkative $(17.1 \%, n=38)$, serious $(11.1 \%, n=25)$ and light-hearted $(8.7 \%, n=19)$. In terms of means and standard deviations (SD), the highest values were scored for honest with a mean of $3.58(\mathrm{SD}=0.599)$ and informative with a mean of $3.57(\mathrm{SD}=0.600)$. The lowest values were scored by quiet with a mean of $2.28(\mathrm{SD}=1.108)$ and talkative with a mean of 2.60 (SD = 1.057). To simplify the portrayal of important and unimportant personality traits, the initial four-point scale was reduced to a two-point scale. Important and Most important were merged, as were Unimportant and Not sure if it is important. Most respondents $(n=237,96.7 \%)$ chose gentle as being an important personality trait for a mammographer, whilst mature received the least votes $(n=183,80.2 \%)$. Table 2 presents the rating of the personality traits.

\section{Four factors}

Factor analysis identified four factors on the personality trait scale. All the items of factors ' 1 ' to ' 3 ' seem to describe various aspects of a professional attitude and demeanour, whilst the items of factor ' 4 ' tend to refer to personal attributes of the mammographer that may influence interaction between the respondent and the mammographer. The reliability of factor 1 (trust) is high, with a Cronbach's alpha of 0.911 and interitem reliability higher than 0.7 for all the items. Reliability of factor 2 (care) is also high, with a Cronbach's alpha of 0.904 and inter-item reliability scores all higher than 0.7. The Cronbach's alpha for factor 3 (being safe) is 0.933 and interitem reliability scores are all higher than 0.7 . The items of

TABLE 1: Patient demographics.

\begin{tabular}{lll}
\hline Main variable & Category & \% \\
\hline Age & $20-39$ & 19 \\
& $40-49$ & 32 \\
$50-59$ & 27 \\
Ethnicity & $60+$ & 22 \\
& Asian & 16 \\
& Black people & 12 \\
Marital status & Mixed-race & 19 \\
& White people & 53 \\
Education & Life partner & 66 \\
& No life partner & 34 \\
\hline
\end{tabular}


TABLE 2: Mammographer personality traits in terms of importance or unimportance as per respondents.

\begin{tabular}{lllll}
\hline Number & Important traits & $\mathbf{\%}$ & Unimportant traits & $\mathbf{\%}$ \\
\hline 1 & Approachable & 97.5 & Quiet & 64.2 \\
2 & Honest & 96.7 & Inquisitive & 56.5 \\
3 & Gentle & 96.7 & Talkative & 47.3 \\
4 & Informative & 96.6 & Serious & 39.1 \\
5 & Patient & 96.6 & Light-hearted & 32.4 \\
6 & Friendly & 95.5 & - & - \\
7 & Considerate & 95.4 & - & - \\
8 & Dedicated & 94.4 & - & - \\
9 & Attentive & 93.9 & - & - \\
10 & Observant & 93.5 & - & - \\
11 & Calm & 93.1 & - & - \\
12 & Supportive & 92.4 & - & - \\
13 & Positive (attitude) & 92.3 & - & - \\
14 & Courteous & 92.3 & - & - \\
15 & Reassuring & 92.1 & - & - \\
16 & Sincere & 90.9 & - & - \\
17 & Tolerant & 90.2 & - & - \\
18 & Empathetic & 88.7 & - & - \\
19 & Mature & 80.2 & - & - \\
\hline & & & & \\
\hline
\end{tabular}

factor 4 (communication) all appear as unimportant on the list of personality traits, with a reliability score of 0.827 and inter-item reliability scores for three of the items being higher than 0.7. Light-hearted and inquisitive score below 0.7. One-way ANOVA testing compared the mean of the four factors with respondents' age, ethnic group, marital status and educational level. Only the fourth factor (communication), when rated according to educational level, was of statistical significance, with a probability value of 0.000 . Items of this factor (all rated unimportant) were cross-tabulated individually with the respondents' educational level. All combinations were statistically significant $(p \leq 0.002)$ and indicated that as the respondents' level of education increased, so did the unimportance of the individual factors.

\section{Ethical considerations}

The bioethical principle of autonomy was honoured in that patients' participation was anonymous and voluntary. Informed consent was implied once a patient who had read the information letter and indicated willingness to participate, was handed a questionnaire, completed it and placed it into a sealed box. Ethical clearance was granted by the Academic Ethics Committee of the Faculty of Health Sciences, University of Johannesburg (14/08) and the Human Research Ethics Committee (Medical) of the University of the Witwatersrand (M080460) and the targeted centres also approved of the data collection process.

Emotional distress, resulting from the questionnaire, was limited during the mammogram procedure as patients received the questionnaire only after the procedures. Patients benefited only in terms of the possibility of improved future mammograms and the knowledge that they participated in a research project.

\section{Validity and reliability}

A pilot study tested questionnaire validity and, where indicated, changes were made. Reliability of the personality trait scale was tested by means of Cronbach's alpha coefficient and a high internal consistency of 0.954 was displayed.

\section{Discussion}

The four factors that emerged from the personality trait scale were named according to the possible combined effect that their items might have on the perceptions of patients. Figure 1 illustrates the factors, along with their items.

\section{Trust factor}

It is deduced that mammographers who are approachable, honest, informative, gentle, considerate and courteous foster a sense of trust in patients. On closer analysis, being approachable, honest and informative emphasises the need for effective communication and indicate that a mammographer's ability to provide information is valued highly. This finding is supported by literature highlighting the crucial role of mammographers in patient education concerning mammography and general breast health care (Kamm 2000:257). Mammographers should thus be well informed in all fields concerning breast healthcare. In addition, they should be able to answer patients' questions in an appropriate, confident and professional manner.

Gentleness sensitises us to the fact that patients are very aware of the discomfort associated with mammograms and often approach the process with concern and/or apprehension. As physical discomfort pertains mostly to the compression technique, mammographers should apply compression gently whilst explaining its purpose and should also point out that the patient may intervene if it becomes painful (Kamm 2000:252). A strategy that further facilitates a gentle approach is the careful review of

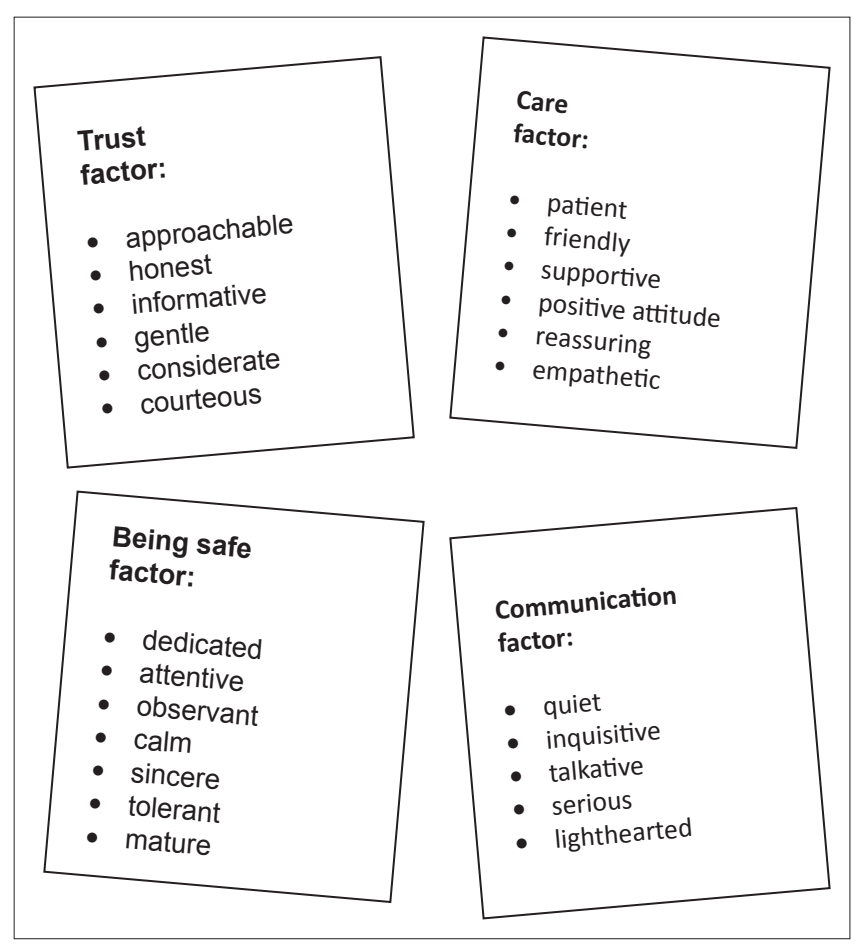

FIGURE 1: Four factors pertaining to mammographer personality traits. 
previous records and images. This alerts mammographers to the effect of medication patients may be using, type of breast parenchyma, possible positioning problems and technique details such as tube angulation and compression that were used previously (Davey 2007:231). Armed with this information, mammographers are able to adapt the imaging technique beforehand so as to avoid unnecessary discomfort.

Courteousness and being considerate refer not only to the professional manner in which all patients should be treated, but also to the way mammographers adapt to the moral philosophy of individual patients from different ethnic, religious and cultural backgrounds. The cultural background of women defines their perception of what is considered a health problem, acceptable treatment, by whom such treatment should be given and their compliance with the treatment (Scott 2007:207). To allow appropriate approaches for different patients, it is thus imperative that mammographers become informed and educated with regard to the different belief systems amongst the wider South African population.

\section{Care factor}

Care can be defined as feeling concern or interest for something or someone (Coulson et al. 1984). Certain of the mammographer personality traits, namely, patient, friendly, supportive, positive attitude, reassuring and empathetic convey a sense of care to patients. The concept of care should be addressed holistically and must be evident from the moment patients make their appointments until they receive the outcome of their test.

From an emotional standpoint, the process involves patience, empathy and friendliness being displayed by all staff. Mammographers, in particular, should take care never to make patients feel rushed and must make every effort to assure patients of their undivided attention (Kamm 2000:254). On the physical side, a caring environment comprises a relaxing ambience with attention to detail such as décor, background music and temperature control (Doyle \& Stanton 2002:164). Literature calls specifically for awareness of the impact of the physical environment on mammogram patients and suggests that mammography departments aim for an atmosphere conducive to minimal apprehension.

If the perception of care is conveyed effectively, it should alleviate patient anxiety and promote general satisfaction with the mammogram experience (Doyle \& Stanton 2002:164). A lack of information regarding the mammogram procedure, as well as concern about the results of the mammogram, contribute to patient anxiety (Doyle \& Stanton 2002:161; Kamm 2000:257). Procedural information prior to the mammogram examination and prompt availability of the mammogram report are thus important elements of a caring regime (Doyle \& Stanton 2002:167; Scott 2007:215).

\section{Being safe factor}

The perception of being safe can be described as resulting from associating with something/someone 'that can be reckoned on' (Coulson et al. 1984). The mammographer personality traits of being dedicated, attentive, observant, calm, sincere, tolerant and mature communicate such a virtue. Combined, these traits will give credibility to a mammographer's efforts to make patients feel safe - efforts that are often enhanced by the mammographer's level of competence and confidence. Confidence on the part of the mammographer is reported to be largely dependent on competence and, because confident mammographers also seem to communicate better with patients than those lacking confidence, measures to grow competence and confidence levels through professional development programmes should be prioritised (Booth 2008:324; Long et al. 2010:579). It is suggested that mammography departments implement programmes attending to the professional expertise of mammographers. They can then optimise the patient's perception of being safe by communicating the professional achievements of the mammographers by means of, for instance, displaying framed certificates (Long et al. 2010:580; Poulos \& Llewellyn 2005:21).

Whilst maturity received the least votes, comparatively, it is still interesting to note that $80 \%$ of the respondents considered it to be an important trait. This finding is affirmed by literature reporting that older mammographers are, in general, perceived as being more of an equal to the average patient with better communication skills and increased empathy and competence (Hazlewood 1999:136).

\section{Communication factor}

This factor comprises the personality traits of being quiet, inquisitive, talkative, serious and light-hearted - all referring to the way in which verbal interaction between mammographer and patient may be negotiated. These traits were all perceived as being the least important on the personality trait scale, but the high votes for approachability, honesty and being informative (trust factor) indicate that communication with mammographers is valued highly. As a result, both verbal and non-verbal interactions will be included in this factor in future. This decision is supported by the emphasis that mammographic literature places on effective communication and the fact that only $35 \%$ of a message is conveyed verbally (Booth 2008:324; Davey 2007:231; Hazlewood 1999:136; Long et al. 2010:581).

Communication in mammography serves to convey the concepts of trust, care and being safe and, as a result, elicits patient understanding and cooperation. Optimised patient understanding and cooperation result in lower repeat rates with reduced radiation doses and also lead to better quality images which facilitate more accurate diagnoses. It is thus an ethical responsibility to promote effective communication in the mammography setting. This opinion was reinforced recently when the matter of informed consent in radiography was raised. As informed consent is a patient right in the South 
African healthcare system, the legal and ethical validity of consent obtained after suboptimal communication is thus questionable (Etheredge 2011:11).

The findings regarding communication are important as they highlight the value of effective communication in mammography in a South African context - an aspect that does not receive sufficient attention in current national training programmes. It is suggested that apart from pure mammographic professional development, qualified mammographers and mammography students be exposed to basic and advanced communication skills that are tailored to the needs of the mammography setting.

\section{Application and implication}

The above factors emerged after statistical analysis of the choices respondents made regarding the personality traits of mammographers. In reality, the impact of specific personality traits cannot be confined to only one of the factors. It is important to understand that the factors are fluid and, apart from the fact that each has its own impact on the mammogram experience, they also influence one another, resulting in a complex amalgamation of facets which has the ultimate role of controlling the perceptions formed by patients. As perceptions impact greatly on how patients ultimately experience the whole mammogram procedure and because the mammographer-patient interaction is known to play an integral role in the way in which patients perceive mammograms, it is suggested that the above factors also be used as fundamental elements of an optimal mammogram experience (Barth et al. 2005:324; Kamm 2000:261; Poulos \& Llewellyn 2005:17).

However, conceptualisation of the optimal experience cannot be based solely on patient preferences and perceptions, but should also take into consideration the professional knowledge and skills required by a mammographer. Whilst training courses accredited by the Health Professions Council of South Africa (HPCSA) are accepted as meeting requirements, the traditional knowledge and skills required by the profession should be assessed in terms of the current South African context. Breast healthcare in the public sector is under pressure because of a lack of infrastructure and expertise (Apffelstaedt 2008; Noorlander n.d.) and adaptations to mammographer training programmes could provide cost-effective options for dealing with the dilemma presented by under-resourcing in this sphere (Apffelstaedt 2008; Noorlander n.d.). It is argued that a well-trained breast-imaging specialist who is capable of performing both mammographic and ultrasound imaging as well as basic image interpretation and limited work-up procedures, could effectively shorten the period between the first consultation with a patient and her subsequent treatment. As timely treatment is often less aggressive and more costeffective, it should, together with increased attendance rates, be viewed as an important outcome of the optimal mammogram experience.

Figure 2 depicts the elements of an optimal mammogram experience as currently perceived by the researcher. This concept is by no means absolute and should be developed and populated through extensive future research. It is, however, regarded as a holistic approach to the inception of an optimal mammogram experience in South Africa, as it considers patient preferences and perceptions as well as professional requirements that would address the needs of populations serviced by both the public and private sector.

\section{Limitations of the study}

The decision not to have assistants helping respondents with the questionnaire to avoid bias, because of the fact that the questionnaire tested emotions, preferences and perceptions of a very personal nature, might be the reason why some questionnaires were not completed in full. It is thus suggested that with careful consideration of the difficulties that accompany the use of assistants, future studies should make use of trained assistants so as to increase the number of fully-completed questionnaires. The questionnaire was also not translated from English into other languages in an attempt to avoid varying translations of the concepts of personality traits. This, however, means that some participants may have been excluded from the study. It must also be realised that the traditional criticism of factor analysis as a reliable statistical method for the accurate indication of factors representing different dimensions of personality is also applicable to the personality trait scale used in this research (Wikipedia n.d.).

\section{Recommendations for future research}

Extensive further research is indicated regarding the four factors which emerged from the different mammographer personality traits. It was not within the scope of the research reported in this article to venture extensively into the specialised field of personality traits, thus the list of

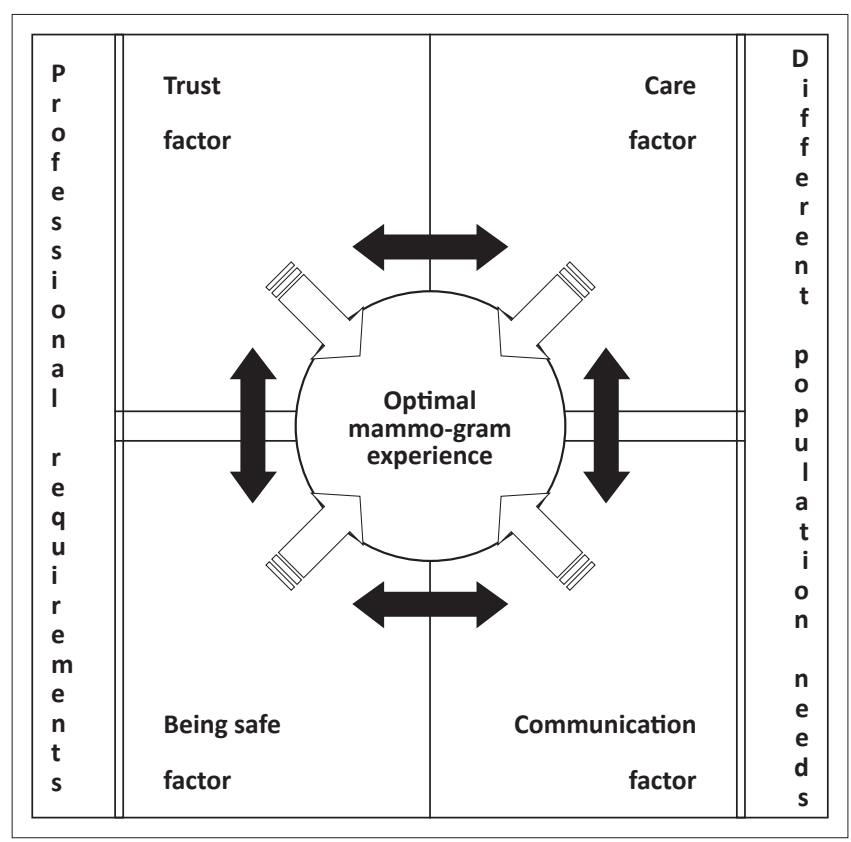

FIGURE 2: Elements contributing to an optimal mammogram experience. 
personality traits used was compiled from traits identified in existing literature. There is little doubt that those traits were mostly identified within the context of mammography and with little consideration of well-known personality trait models, of which the Big Five is one (Srivastava n.d.). However, from the globally-accepted important personality traits of a mammographer, four benchmark factors were identified within the South African context. This then has the potential to serve as the basis for future research, where the vast knowledge within the personality trait domain can be merged into the immature body of knowledge within the mammographic sphere.

\section{Conclusion}

The factors trust, care, being safe and communication were deduced from responses made by South African women as being important in the mammogram experience. Although the study was performed in only four centres in Gauteng, the study was able to produce baseline information regarding factors that play a role in patient perceptions. It can thus be used as a point of departure for future research and for the development of initiatives that will improve current perceptions concerning mammography amongst South African women.

The research findings also launched the process of conceptualising the optimal mammogram experience for a South African population. The suggested concept is, however, just the beginning of a process; development of a final and feasible concept will only be possible with input from the various breast healthcare stakeholders. As a consequence, reflection on existing training programmes and the relevance of the current professional scope of mammographers in South Africa might be indicated.

\section{Acknowledgements}

This article is based on the MTech study by the first author, titled Preferences and perceptions of female patients undergoing mammography in Gauteng, South Africa.

Results of the above study were also presented at a South African Association for Health Educationalists (SAAHE) conference on 30 June 2011, under the title Conceptualising the optimal mammogram experience and the role of education in the inception thereof in South Africa.

\section{Competing interests}

The authors declare that they have no financial or personal relationship(s) that may have inappropriately influenced them in writing this article.

\section{Authors' contributions}

A.L. (University of Johannesburg) was the MTech candidate/researcher for this article, H.L. (University of Johannesburg) was research supervisor and J.M. (University of Johannesburg) was the research co-supervisor.

\section{References}

Apffelstaedt, J., 2008, The status of breast health management in South Africa, viewed 29 March 2010, from http://www.bizcommunity.com/ Article/196/335/24909.html

Barth, R.J., Gibson, G.R., Carney, P.A., Mott, L.A., Becher, R.D. \& Poplack, S.P. 2005 , 'Detection of breast cancer on screening mammography allows patients 2005 , 'Detection of breast cancer on screening mammography allows patients
to be treated with less-toxic therapy', American Journal of Roentgenology to be treated with less-toxic therapy', American Journal of R
184(1), 324-329. http://dx.doi.org/10.2214/ajr.184.1.01840324

Booth, L., 2008, 'The radiographer-patient relationship: Enhancing understanding using a transactional analysis approach', Radiography 14(4), 323-331. http:// dx.doi.org/10.1016/j.radi.2007.07.002

Coulson, J., Carr, C.T., Hutchinson, L. \& Eagle, D., 1984, The Award Illustrated Dictionary, 2nd edn., Award Publications, London.

Davey, B., 2007, 'Pain during mammography: Possible risk factors and ways to alleviate pain', Radiography 13(3), 229-234. http://dx.doi.org/10.1016/j. radi.2006.03.001

Doyle, C.A. \& Stanton, M.T., 2002, 'Significant factors in patient satisfaction ratings of screening mammography', Radiography 8(3), 159-172. http:// dx.doi.org/10.1053/radi.2002.0379

Etheredge, H., 2011, 'Rethinking responsibility in radiography: Some ethical issues in South Africa', South African Journal of Radiology 16(1), 10-13.

Farmer, D., Reddick, B., D’Agostino, R. \& Jackson, S.A., 2007, 'Psychosocial correlates of mammography screening in older African American women' Oncology Nursing Forum 34(1), 117-123. http://dx.doi.org/10.1188/07. ONF.117-123

Fowler, B.A., 2006, 'Social processes used by African American women in making decisions about mammography screening', Journal of Nursing Scholarship 38(3), 247-254. http://dx.doi.org/10.1111/j.1547-5069.2006.00110.x

Hazlewood, J., 1999, 'The importance of communication skills for breast screening radiographers', The Radiographer 46(3), 135-138.

Health Professions Council of South Africa, 2008, National Patients' Rights Charter: Guidelines for good practice in the health care professions, HPCSA, Pretoria.

Ikeda, D.M., 2004, Breast imaging - the requisites, Elsevier, Philadelphia.

Kamm, B.L., 2000, 'Communicating with mammography patients', Radiologic Technology 71(3), 247-264.

Legg, J.S., 2000, 'Provider efforts to increase mammography screening', Radiologic Technology 71(5), 435-440.

Long, S.M., Miller, L.C., Botsco, M.A. \& Martin, L.L., 2010, The handbook of mammography, 5th edn., Mammography Consulting Services, Ltd, Edmonton.

Noorlander, A., n.d., Breast cancer month - South Africa, viewed 29 March 2010, from http://www.ehow.com/about 5290661 breast-cancer-monthsouthafrica.html

Peart, O., 1994, 'Helping patients overcome their fear of mammography', Radiologic Technology 66(1), 34-38.

Pinklink, 2007, Breast cancer: where do we go from here?, viewed 10 May 2009 from http://www.pinklink.org.za/Pages/Section.asp?SectionID=1320

Poulos, A. \& Llewellyn, G., 2005, 'Mammographic discomfort: A holistic perspective derived from women's experiences', Radiography 11(1), 17-25. http://dx.doi.org/10.1016/j.radi.2004.07.002

Scott, A., 2007, 'Improving communication for better patient care', Radiologic Technology 78(3), 205-218.

Srivastava, S., n.d., Measuring the big five personality domains, viewed 28 April 2014, from http://psdlab.uoregon.edu/bigfive.htm

Swan, J., Breen, N., Coates, R.J., Rimer, B.K. \& Lee, N.C., 2003, 'Progress in cancer screening practices in the United States: Results from the 2000 National Health Interview Survey', Cancer 97(6), 1528-1540. http://dx.doi. org/10.1002/cncr.11208

Wikipedia, n.d., Big five personality traits, viewed 28 April 2014, from http:// en.wikipedia.org/wiki/Big_Five_personality_traits 